Whaling

\section{US and Japan agree to disagree}

Tokyo

ANGRY criticism from press and politicians has greeted the Japanese government's decision to bow to US pressure and stop all sperm whaling by 1988 . But there is some confusion over exactly what Japan has agreed to, with conflicting announcements in Washington and Tokyo, and protests from Greenpeace (the environmental pressure group) that Japan has got off far too lightly.

According to US negotiators, Japan has agreed to end by 1988 not just sperm whaling but all whaling. With this agreement, the United States hopes to avoid the bad feelings that would arise if, instead, it tried to use cuts in fishing quotas to force Japan

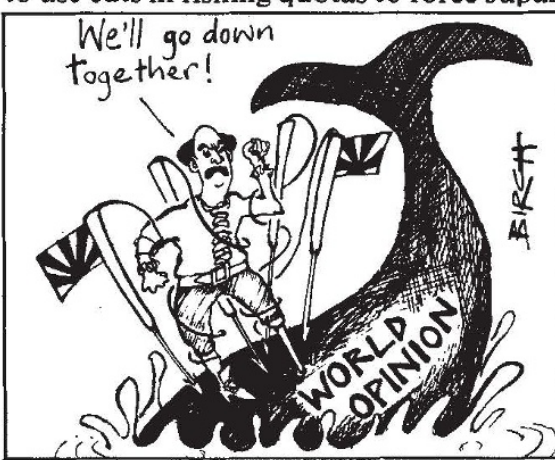

to abide by the rulings of the International Whaling Commission (IWC) that sperm whaling should end this year, and all commercial whaling next year. But Japanese officials claim they have agreed to end only sperm whaling by 1988 and that a ban on whaling altogether is only a US offer. And an angry statement from Hiroya Sanyo, the Fisheries Agency director general who headed the Japanese delegation, adds that the talks had been "unfair" and "outside the bounds of normal diplomacy",

Anti-whaling groups in Western nations are equally angry that Japan is now to be given until 1988 to end sperm whaling. An injunction is to be sought to force the US government to obey the PackwoodMagnusson Amendment to the 1979 Fishery Conservation and Management Act and impose cuts in Japan's fishing quotas the moment Japanese boats catch a sperm whale - and there are unconfirmed reports that two whales have already been caught.

The Packwood-Magnusson Amendment provides that when a nation "diminishes the effectiveness" of an international whaling agreement, it must be "certified" by the US government, which means that that nation's quota in the US 200-mile zone must be cut by at least half in the first year of certification and by 100 per cent in the second year. The outcome of court action is now likely to hinge on the meaning of the words "diminish the effectiveness", with the US government arguing that with the new agreement the effectiveness of the of 16 three-month legs. projects.
IWC ruling is not diminished.

Japan is, in any case, far more concerned about minke whales than sperm whales. At the same IWC 1984 meeting where the sperm whale quota was cut to zero, the Antarctic minke whale quota - upon which Japan's offshore whaling industry depends - was cut to 4,224 to be shared between Japan, the Soviet Union and Brazil. Both the Soviet Union and Brazil have formally objected to the quota, thus freeing themselves from obligation to abide by it. Japan has not so far objected because of its fear that US fishery cuts would follow. But immediately after the new agreement with the United States was announced, the agriculture, forestry and fisheries minister Moriyoshi Sato stated that Japan will file an objection to the minke whale quota before the deadline of 6 January. The following year, the minke whale quota would automatically fall to zero as the total ban on whaling agreed by IWC in 1982 comes into effect.

It seems clear that the minke whale quota has been the subject of a US offer that goes over IWC's head: a blind eye would be turned to further whaling in the next three years and no fishing quota cuts would be imposed, provided Japan will compromise and agree to stop all whaling by 1988 . Washington has apparently gone so far as to claim that Japan has already agreed to accept this offer. The subsequent announcement from Mr Sato suggests, however, that Japan will still fight on and try to win some further concessions from the United States - if legal action does not in the meantime undo what has already been achieved.

Alun Anderson

\section{Around the world in four years}

OPERATION Raleigh, a four-year circumnavigation of the world that plans to mount over 150 scientific projects in more than 30 countries, was launched last week by its British patron, the Prince of Wales. The flagship of the expedition, named for Sir Walter Raleigh who sponsored the first English-speaking colony in North America $\mathbf{4 0 0}$ years ago, sailed from Kingston upon Hull last week for the Bahamas, on the first

The expedition is modelled on Operation Drake (1978-80) and is organized by the Scientific Exploration Society Ltd, a registered charity. Operation Raleigh will involve over 300 scientists, assisted by 4,000 selected young people, 75 per cent of whom will come from the United States and Britain. The ship is equipped with three scientific laboratories largely donated by Gallenkamp, diving facilities including a decompression chamber, a Marisat satellite communications system and a computer centre donated by Acorn Computers Lid and Centronics, and will support both marine and land-based

The first leg of the expedition to the Bahamas and Turks and Caicos Islands in the West Indies will include a biological

and geological investigation of the "blue holes" system of the Bahamian islands underwater caves and tunnels carved out by the dissolution of limestone rocks by fresh water at a time (about 18,000 years ago) when the sea level was about 100 metres lower than it is now.

The Bahamas will also be the first site in a "reefwatch" programme to monitor the effects of sediment pollution on coral reefs. Coastal accumulation of sediment resulting from forest clearance reduces the amount of light penetrating the coral, which has an adverse effect on the photosynthesis of the symbiotic algae on which reef-building corals depend for their survival.

Operation Raleigh, operating as it does mainly from tropical latitudes, might be considered a "jamboree" for the scientists involved, but the main criterion used by the Scientific Research Committee in selecting projects - which must be more or less selffinancing - was that the work should produce results suitable for publication in research journals. The young people who will provide semi-skilled assistance on the expedition were also subject to rigorous selection procedures.

Peta Pickering

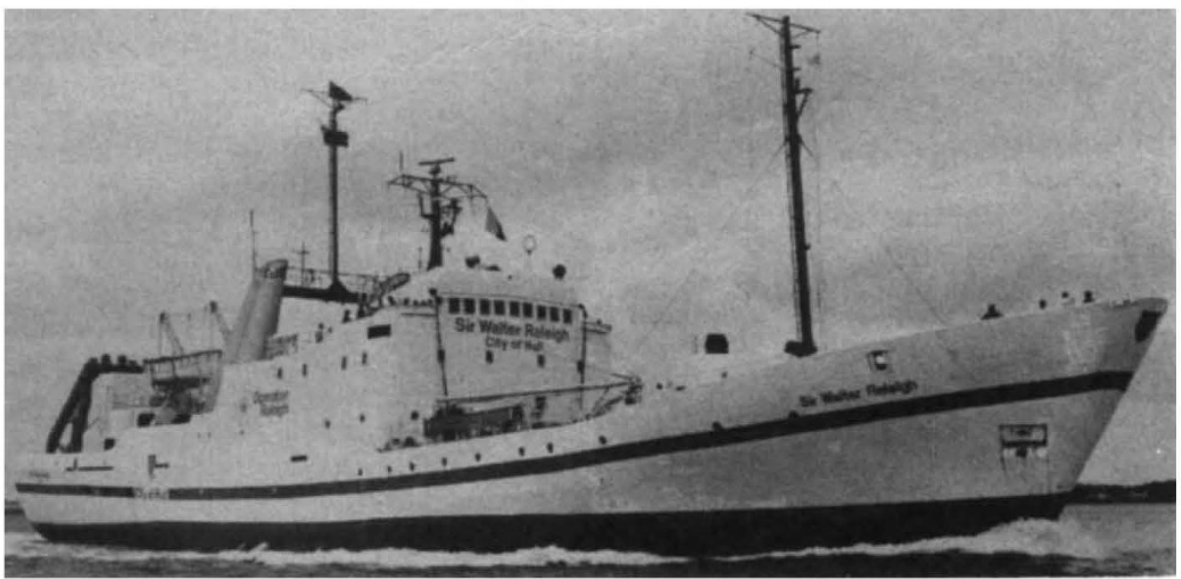

